\title{
Doctors' Challenges During Infectious Disease Outbreaks: Medical Education Insights from Realistic Fiction Movies
}

This article was published in the following Dove Press journal:

Advances in Medical Education and Practice

\author{
Suhad Daher-Nashif \\ Population Medicine Department, \\ College of Medicine, QU-Health, Qatar \\ University, Doha, 27I3, Qatar
}

Background: Movies have a strong influence on public perceptions due to their popularity and accessibility. Hence, movies on healthcare providers in general and medical doctors in particular can affect public opinions, expectations, and attitudes toward these professions.

Aim: This paper aims to present how realistic fiction movies reflect doctors' roles and challenges during infectious disease outbreaks and describe how some of this content can be used in medical education settings.

Methods: Two sources were used to select the movies for inclusion in the study. First, the IMDB.com movie database was searched using the words "virus," "pandemic," "endemic," "epidemic," "outbreak," and "infectious disease." Second, Google was used to search the terms "movies on pandemics," "movies on epidemics," "movies on outbreaks," "movies on endemics," "movies on virus," and "movies on infectious diseases." Inclusion criteria were English language movies, realistic fiction movies, doctors as main actors, and a movie focus on community experiences. Exclusion criteria were non-English movies, zombie and apocalypse movies, doctors in secondary roles, and movies about individual experiences.

Results: Eight movies met the inclusion criteria. Content analysis was conducted on all movies, and the main categories identified were doctors' roles, doctors' vulnerability, potential biases, potential conflicts, female doctors' power, and doctors bringing salvation.

Conclusion: Realistic movies on infectious disease outbreaks can be excellent tools for teaching medical students about doctors' roles and challenges when fighting an outbreak.

Keywords: realistic movies, infectious disease outbreak, doctors' experiences, medical humanities, medical students

\section{Introduction}

The single biggest threat to man's continued dominance on the planet is the virus.

This statement from Joshua Lederberg, Ph.D. and Nobel laureate, opens the film Outbreak (1995), reminding viewers that despite their expertise and hard work, doctors are humans without superpowers or magic bullets to defeat infectious diseases. The word "doctors" in this context refers to physicians, i.e., medical doctors. Outbreak is one of many realistic fictional films on infectious disease outbreaks released between 1914 and 2019. In general, films have a powerful influence on popular culture due to their international popularity, easy accessibility, and profitability as an industry. ${ }^{1}$ Cinematic depictions of doctors thus have the potential to affect public expectations and doctor-patient relationships. ${ }^{1}$ In a 2002
Correspondence: Suhad Daher-Nashif Population Medicine Department, College of Medicine, QU-Health Qatar University, Doha, 27I3, Qatar

Email snashif@qu.edu.qa
Advances in Medical Education and Practice 2021:12 265-272

submit your manuscript

DovePress f in $\mathbf{D}$ 
study, Flores conducted an in-depth analysis of the portrayal of doctors in films, reviewing 131 films from nine countries across eight decades. Flores found that while compassion and idealism were common in early movie portrayals of doctors, they have become increasingly scarce in recent decades. ${ }^{1}$ Furthermore, Flores determined that since the 1960s, positive portrayals of doctors have declined while negative portrayals have increased; the theme of the "mad scientist" doctor who values research over patient welfare has become common. Flores concluded that films about doctors can serve as useful measures of public opinion and tools for medical education. ${ }^{1}$

In his review of films on infectious diseases between 1914 and 2019, Dehority ${ }^{2}$ found that eight of the nine earliest outbreak depictions (1914-1957) feature the selfless heroism of medical professionals. Dehority argued that after 1957, films began depicting the dangers of alien microbes, which threatened our newfound confidence in antibiotics. He continued his review by stating that the 1960s and 1970s produced 16 films, and in keeping with the dawning ecological movement of the time, ushered in a darker era of pandemic movies portraying environmental destruction. $^{2}$ Dehority's study reviewed 80 Hollywood movies involving infectious disease outbreaks and pandemics, including unrealistic films such as zombie and apocalypse movies. The current study chooses to include only realistic fiction movies because it aims to understand how the lived experience of doctors is reflected in films involving infectious disease outbreaks. Realism in film is a style that creates the illusion of reality, of being a "slice of life," wherein the director attempts to depict the surface of lived experience as closely as possible so that viewers accept the film as a reflection of reality. ${ }^{3}$ The chosen timeframe for this review, which analyzed movies released between 1990 and 2019, stems from the desire to include movies that are relevant to today's medical practice. The study also recommends potential uses of these movies with medical students. Although there is still a lack of evidence-based knowledge on how movies contribute to medical education, especially in terms of their long-term impact, movies are an effective tool in medical education. $^{4-6}$ For example, in their pilot study, Lumlertgul et $\mathrm{al}^{7}$ used five films to teach their medical students about professionalism. They argued that through these films, their students developed a deeper understanding of five main ethical issues: the doctor-patient relationship; informed consent and clinical trials; the management of genetic disorders; patient management; and brain death and organ transplantation.

Some scholars have criticized the use of films in medical education due to the unrealistic and horrific realities they present $^{8,9}$ and/or because in some cases, they offer incorrect information or negative portrayals of patients. ${ }^{10}$ In particular, the use of films as a teaching tool in psychiatry has been criticized because of films' unrealistic portrayals of mental illness. ${ }^{10}$ Nevertheless, I argue that even incorrect and negative presentations of patients and/or healthcare providers in movies, can be used to stimulate discussion, criticism, and analysis by medical students. Thus, this study reviews and analyzes the content of realistic movies and answers the main question: how realistic fiction movies portray doctors' experiences while they fight an infectious disease outbreak?

\section{Methods}

The study gathered data by reviewing movies on infectious disease outbreaks released between 1990 and 2019.

\section{Search Strategy}

Two sources were used to locate relevant movies. The first was the IMDB.com movie database, which was searched using the words "virus," "pandemic," "endemic," "epidemic," "outbreak," and "infectious disease." The second source was a Google search for the terms "movies on pandemics," "movies on epidemics," "movies on outbreaks," "movies on endemics," "movies on viruses," and "movies on infectious diseases." Eighty-seven movies were found in the first search, of which eight met the inclusion criteria.

\section{Inclusion Criteria}

The inclusion criteria were English language movies with realistic storylines focusing on outbreaks themselves (i.e., not set pre- or post-outbreak) and with doctors playing a primary role in the plot.

\section{Exclusion Criteria}

The exclusion criteria were non-English language movies with unrealistic storylines (Such as zombies and apocalypse movies), and movies without doctors or with doctors in a secondary role. Since outbreaks are public health events, movies about individuals or only one or two families were also excluded.

\section{Data Extraction and Analysis}

The author watched each of the eight movies twice and thematically analyzed them. Thematic analysis is a method 
for identifying, organizing, and offering insights into patterns of meaning (themes) across a data set. ${ }^{11}$ The analysis began with searching for patterns or themes in the movies, reviewing the identified themes, and naming them.

\section{Findings' Validation}

To achieve validity, the researcher followed the validation steps recommended in qualitative research and thematic analysis, ${ }^{12}$ which included obtaining an expert opinion to confirm the themes. Theme were confirmed in conjunction with an expert in qualitative research and cinema who had watched all movies before discussing them with the author. The author also watched the movies twice to ensure the accuracy of the presented themes. Finally, to validate the results, this study presents only data that emerge directly from the movies and does not include data from secondary resources.

\section{Findings}

Eight movies met the inclusion criteria: 93 Days (2016); Contagion (2011); Pandemic, Part II (2009); Toxic Skies (2008); Pandemic, Part I (2007); Contagious (1997); Outbreak (1995); and Virus (1995). Further details on each movie are given in Table 1. The thematic analysis of the selected movies provided six main themes: the role of doctors during outbreaks, the vulnerability of doctors, potential biases, potential conflicts, the power of female doctors, and doctors bringing salvation.

\section{Doctors' Roles}

Doctors in the eight movies play several roles that show how doctors can manage infectious disease outbreaks in real life. Most of the movies feature more than one doctor and more than one medical role. In 93 Days, Dr. Ameyo leads the medical team at First Consultant Medical Center in Lagos, Nigeria. She insists on keeping a patient (a diplomat from Liberia) in the hospital until they diagnose the disease. Dr. Benjamin, the hospital manager, approves her decision, follows up on infected team members, and deals with Liberia's ambassador, who demands the diplomat be released from the hospital. Doctors also act as representatives of international organizations such as the World Health Organization (93 Days, Contagion, and Toxic Skies) and the Center for Disease Control (Contagion, Outbreak, and Virus). These representatives help states manage the outbreaks in infected cities and prevent the spread to other cities. Collaboration between doctors with different specialties is clearly represented in all the movies, both in the fight against the diseases themselves and in preventing the unethical or illegal actions of other doctors or stakeholders. Furthermore, collaboration with health organizations and other team members contributes to preventing epidemics from becoming pandemics. Doctors in the movies also help to identify "patient zero" and disease carriers, playing the roles of epidemiologists (Contagious and Contagion), on-site health care providers (93 Days, Pandemic, Contagious, Outbreak, and Virus), and officers in military medical units (Outbreak). Their social roles outside of their positions as medical professionals are also represented. For example, the roles of doctors within their families become important when family members are infected (Pandemic I \& II, Contagious, and Outbreak). Their representation in multiple roles reflects the multidisciplinary nature of practicing medicine and the key responsibilities doctors adopt during outbreaks.

\section{Doctors' vulnerability}

In their various professional roles, the doctors in these movies are portrayed in ways that showcase their fundamental humanity as well as their medical skills. One example is the recurring theme of the personal vulnerability of doctors, which is visible in their inability to prevent family members from becoming infected. In Contagious, Dr. Cole's husband and son are infected, in Pandemic, Dr. Martin's sister is infected, and in Outbreak, the infected loved one is Dr. Daniels' wife (Dr. Keough). In addition, in some movies, the doctors themselves become infected, and in two movies, they die from the virus. Vulnerability to infection is part of being a doctor; this vulnerability reflects their humanity. The movies analyzed in this study show that a doctor is not only a hero but also a vulnerable human being who may indeed perish. In these movies, when doctors or their family members become infected, their reaction is sorrow and fear. For example, Dr. Mears in Contagion cries when she calls her manager at the CDC to tell him that she is infected. This realistically reflects the human aspect of those whom the general public tends to view only as heroes, highlighting that doctors and their families are among the most vulnerable during outbreaks and make notable sacrifices for public safety. ${ }^{7} 93$ Days opens with Dr. Igonoh in an ambulance on her way to the isolation center, reflecting on human vulnerability:

Most of us live our lives without ever thinking, without ever really seeing, without ever really understanding how 
Table I Movies Representing Physicians' Work During Infectious Disease Outbreaks, 1990-2019

\begin{tabular}{|c|c|c|c|c|c|}
\hline Title & Year & Country & Directed by & Main Cast & Synopsis \\
\hline Outbreak & 1995 & USA & Wolfgang Petersen & $\begin{array}{l}\text { Morgan Freeman (Brigadier } \\
\text { General Billy Ford, MD) } \\
\text { Dustin Hoffman (Colonel Sam } \\
\text { Daniels, MD) } \\
\text { Rene Russo (Dr. Robby Keough, } \\
\text { CDC scientist) } \\
\text { Kevin Spacey (Maj. Casey } \\
\text { Schuler, MD) }\end{array}$ & $\begin{array}{l}\text { A monkey was brought from } \\
\text { Africa to America, carrying } \\
\text { a deadly virus. The army } \\
\text { doctors struggled to find the } \\
\text { monkey, to find the cure for the } \\
\text { virus, and to control the rapid } \\
\text { spread of the virus in California. }\end{array}$ \\
\hline Virus (Formula for Death) & 1995 & USA & $\begin{array}{l}\text { Armand } \\
\text { Mastroianni }\end{array}$ & $\begin{array}{l}\text { Nicollette Sheridan (Dr. Marissa } \\
\text { Blumenthal) } \\
\text { William Devane (Dr. Harbuk) } \\
\text { Dakin Matthews } \\
\text { (Dr. Dubchenk) } \\
\text { Kurt Fuller (Dr. Williams) }\end{array}$ & $\begin{array}{l}\text { A doctor who insisted on } \\
\text { searching for the truth behind } \\
\text { a deadly plague spreading through } \\
\text { the largest American urban area } \\
\text { found herself targeted for death. } \\
\text { Slowly she discovered that the } \\
\text { unexplained plague may have } \\
\text { been unleashed by racist } \\
\text { members of the medical } \\
\text { establishment itself. }\end{array}$ \\
\hline Contagious & 1997 & USA & Joe Napolitano & $\begin{array}{l}\text { Lindsay Wagner (Dr. Hannah } \\
\text { Cole, Epidemiologist, MD) } \\
\text { Elizabeth Peña (Detective Luisa } \\
\text { Rojas) }\end{array}$ & $\begin{array}{l}\text { The movie described an } \\
\text { outbreak of cholera carried by } \\
\text { shrimp from Colombia which } \\
\text { was served on an airplane } \\
\text { bound for Los Angeles. While } \\
\text { a doctor set out to find the } \\
\text { outbreak's source and contain it } \\
\text { before it became an epidemic, } \\
\text { her husband and son were } \\
\text { infected as well. }\end{array}$ \\
\hline $\begin{array}{l}\text { Pandemic, Parts I } \\
\text { A deadly virus was carried by } \\
\text { a traveler from Australia to LA, } \\
\text { and most of the travelers in the } \\
\text { airplane became infected. The } \\
\text { case was identified, and the } \\
\text { travelers were quarantined in } \\
\text { a special section in a hospital. One } \\
\text { traveler managed to sneak out and } \\
\text { caused a rapid spread of the virus. } \\
\text { The movie focuses on the } \\
\text { healthcare providers' struggle to } \\
\text { control the cases and find an } \\
\text { effective cure. }\end{array}$ & \& II & $\begin{array}{l}2007 \\
2009\end{array}$ & USA & Armand Mastroianni & $\begin{array}{l}\text { Tiffani Thiessen (Dr. Kayla } \\
\text { Martin) French Stewart } \\
\text { (Dr. Carl Ratner) Faye Dunaway } \\
\text { (Governor Lillian) Eric Roberts } \\
\text { (Mayor Dalesandro) } \\
\text { "The bird flu virus spreads } \\
\text { through Los Angeles as a doctor } \\
\text { from the CDC races to find } \\
\text { a vaccine." }\end{array}$ \\
\hline
\end{tabular}

(Continued) 
Table I (Continued).

\begin{tabular}{|c|c|c|c|c|c|}
\hline Title & Year & Country & Directed by & Main Cast & Synopsis \\
\hline Toxic Skies & 2008 & Canada & Andrew C. Erin & $\begin{array}{l}\text { Anne Heche (Dr. Tess Martin, } \\
\text { WHO) Daniel Bacon (Dr. Raj } \\
\text { Patel) Nicola Anderson (Nurse } \\
\text { Emily) }\end{array}$ & $\begin{array}{l}\text { The movie highlights Dr. Tess } \\
\text { Martin's struggles to find the } \\
\text { cure for a sudden pandemic } \\
\text { while she reveals the } \\
\text { government's secret chemo-trail } \\
\text { program as the cause for that } \\
\text { pandemic. }\end{array}$ \\
\hline Contagion & 2011 & USA & Steven Soderbergh & $\begin{array}{l}\text { Gwyneth Paltrow (Beth Emhoff) } \\
\text { Matt Damon (Mitch Emhoff) } \\
\text { Kate Winslet (Dr. Erin Mears, } \\
\text { CDC) Laurence Fishburne } \\
\text { (Dr. Ellis Cheever) Jude Law } \\
\text { (journalist and social media } \\
\text { activist) Marion Cotillard } \\
\text { (Dr. Leonora Orantes, WHO) }\end{array}$ & $\begin{array}{l}\text { The sudden death of a woman } \\
\text { traveling back from China } \\
\text { revealed the rapid spread of } \\
\text { a global pandemic. The movie } \\
\text { focuses on the collaboration } \\
\text { between healthcare } \\
\text { professionals, governments, } \\
\text { CDC teams, and other relevant } \\
\text { systems in finding the cure and } \\
\text { fighting further spread. The } \\
\text { movie also describes social } \\
\text { reactions to the pandemic and } \\
\text { the governments' management } \\
\text { of it. }\end{array}$ \\
\hline 93 Days & 2016 & Nigeria & Steve Gukas & $\begin{array}{l}\text { Bimbo Akintola (Dr. Adadevoh } \\
\text { Ameyo) Somkele lyamah } \\
\text { (Dr. Ada Igonoh) Alastair } \\
\text { Mackenzie (Dr. David, WHO) } \\
\text { Danny Glover (Dr. Benjamin } \\
\text { Ohiaeri) }\end{array}$ & $\begin{array}{l}\text { A diplomat from Liberia came } \\
\text { to Lagos carrying the Ebola } \\
\text { Virus. The movie describes how } \\
\text { local medical teams attempted } \\
\text { to control the spread of the } \\
\text { virus, and how in the process, } \\
\text { they became infected, suffered, } \\
\text { died, and lost their loved ones. }\end{array}$ \\
\hline
\end{tabular}

complicated we are, how connected we are, how very fragile we are.

\section{Potential Biases}

Another aspect of doctors' humanity observed in many of the reviewed movies is their capacity for bias. In four movies (Pandemic I

\& II, Contagious, and Outbreak), doctors give the developed cure, i.e., the potential vaccine, to an infected family member first. Although there are risks in being the first to try a new vaccine, these acts are portrayed as motivated by love and fear for the life of a loved one rather than the willingness to take a risk to save others. Furthermore, in two of the movies (Outbreak and Contagion), doctors steal potentially life-saving vaccines from previous outbreaks and administer them to themselves. Bias is also revealed when doctors tell their loved ones to leave areas where outbreaks are taking place (Dr. Cheever in Contagion and Dr. Daniels in Outbreak) and when state or military powers offer the first vaccines to doctors and their families. For example, in Contagion, Dr. Cheever, head of the CDC, tells his wife to leave the city and gives her one dose of the vaccine; he gives his own dose to the son of the man who cleans the CDC building. In Outbreak, Dr. Daniel tells his wife (Dr. Keough) to leave the city when he realizes that the military intends to bomb the infected city to prevent the epidemic from becoming a pandemic.

\section{Potential Conflicts}

Several movies present a conflict between doctors and other powers. For example, in Outbreak, a direct confrontation emerges between the doctors and the state military 
forces responsible for managing the outbreak and the resulting social chaos. Subsequently, Dr. Daniels confronts the two young soldiers transporting the bomb to the infected city. The soldiers are conflicted; on the one hand, their general has ordered them to release the bomb, but on the other hand, right in front of them in a helicopter, Dr. Daniels is appealing to their humanity to convince them not to release it. In the end, they release the bomb into the sea. In addition to opposing the decisions of military personnel, doctors also contend with criminals (Pandemic I

\& II), unethical companies (Toxic Skies), and racism (Virus). Ultimately, the ethical forces defeat both the disease and human evil in all the reviewed movies. These conflicts reflect the responsibility of doctors to not only care for patients and fight diseases but also engage with the social and ethical issues surrounding outbreaks of infectious disease.

\section{Female Doctors' Power}

Although most of the scriptwriters and directors of the eight movies under analysis are men, the main characters are mostly female doctors. In seven of the movies, women make the first diagnosis, manage the outbreak, prevent more deaths, and find the cure 93 Days, Pandemic I

\& II, Toxic Skies, Contagion, Contagious, and Virus). Only Outbreak has a male, Dr. Daniels, as the leading doctor. Still, his wife, Dr. Keough, plays a major role in managing the outbreak through her work at the CDC, and she refuses to leave the city and stays to treat patients. In Virus, Dr. Blumenthal insists on discovering who created the virus, leading to threats on her life. After Dr. Igonoh is infected in 93 Days, she psychologically supports another severely infected woman in the isolation unit, inspires other patients, and gives them hope following her recovery. In Contagious, Dr. Cole makes the correct diagnosis and reveals that malaria is behind the outbreak. She continues working while her husband and son are infected and saves their lives and the lives of many other people in the hospital. Dr. Mears in Contagion is also a key figure in managing the outbreak, locating patient zero and the source of the virus, tracking down potentially infected people, and managing the isolation unit until she herself is infected and perishes. Immediately before her own death, she even gives her coat to a shivering patient lying beside her.

\section{Doctors Bring Salvation}

All eight movies have happy endings and portray doctors as sources of hope for the world. In the process of fighting an outbreak, doctors lose patients, family members, friends, and colleagues. However, their work, alongside the efforts of colleagues, international health organizations, and governmental powers, enables them to overcome "the only threat to human dominance on the planet." Watching these movies can help people envision the end of a pandemic and retain hope. Indeed, history has shown that despite the sadness and pain associated with infectious disease outbreaks, there is an end to every outbreak. ${ }^{13}$ As stated by Dehority, ${ }^{2}$

[p]erhaps, as we collectively enter an uncertain future wrought by COVID-19, some of these films will help us share not only a moment of communal reminiscence but of hope as well.

\section{Discussion}

The movies presented and analyzed in this study show the professional and human aspects of being a medical doctor during an infectious disease outbreak. The multiple roles played by doctors in these movies reflect their many potential duties in managing infectious disease outbreaks. The roles of doctors have changed through history due to a shift in emphasis towards more efficiency and greater accountability. ${ }^{14}$ These changes are similarly reflected in cinematic history. The movies presented in this study showcase the fact that during their heroic fight against viruses, doctors also frequently find themselves fighting unethical decisions and unethical actors who seek to benefit from outbreaks. In other words, the movies reflect how doctors must engage medically, socially, and politically in order to save lives during an outbreak. ${ }^{15}$

While the films analyzed in this study portray the roles and struggles of doctors, they omit several important aspects of doctoring during outbreaks. Among other issues, these movies do not explore an outbreak's impact on the mental and social health of doctors, the stigma associated with outbreaks toward health care providers and/or patients, or how these issues impact the daily lives of patients. Moreover, even these realistic movies do not address the potential impacts of several sociodemographic factors on doctors' performance. The movies in the study also do not address the roles of other medical specialties, e.g., family doctors and oncologists, during outbreaks. For example, Li has discussed the importance 
of family doctors as gatekeepers and supporters of the health system during the COVID-19 pandemic, ${ }^{16}$ and this role is reflected in Adepoju's discussion on how doctors find themselves in two-front fights against two types of infectious disease: COVID-19 and other viruses such as measles. ${ }^{17}$

In addition to doctors' heavy workload, the movies highlight the fact that doctors are among the most vulnerable during outbreaks. ${ }^{18}$ Indeed, during the current COVID-19 pandemic, a high number of doctors have been infected and died. Hence, these movies can be used as an educational tool for medical students to reflect on their fears and the potential sacrifices they may have to make when dealing with crises in their future careers. Since the early 1990s, movies have been used as part of the medical humanities curriculum to teach medical students about human behavior, attitudes toward disease and medicine, and the ethical and professional aspects of medical practice. $^{4-7}$ Historically, physicians first recorded patients on film for the benefit of teaching medical students in the early $1890 \mathrm{~s}^{8}$ Another aspect of a doctor's work that was presented in the eight movies and can be raised for further discussion with medical students is the potential bias towards saving a beloved family member. This bias highlights the challenges and dilemmas faced by doctors and the ethical conflicts that complicate objective decision-making when family members are infected or become involved in their medical practice. ${ }^{19,20}$

Meanwhile, the portrayals of female doctors as leaders in the management of outbreaks indicate general perceptions of and attitudes toward the power of women as doctors. Despite these key leading roles, these movies highlight the importance of multi-disciplinary teamwork and support from both male and female colleagues during the struggle against infectious diseases. With the increasing number of female medical students and women graduating from medical schools, this is an important topic which can be employed as a tool for empowering female students in medicine. The presence of female doctors in the majority of these movies, along with their depictions of victory over infectious diseases, contributes to the movies' hopeful and positive portrayals of the medical profession. However, hopes of overcoming both outbreaks and gender disparities in medicine would be stronger if these movies had also fairly represented doctors of color and/or ethnic minority doctors, like Black doctors. With the exception of 93 Days, which portrays Ebola in Nigeria, the majority of medical doctor leaders in the movies are white and uppermiddle class. Although the continued portrayal of whiteness as the standard in medicine sends a negative message, it can also be a profoundly important catalyst for deeper discussions of the representation of Black doctors and patients in movies and medical books.

\section{Conclusion}

Realistic movies depict the real-life roles and experiences of medical doctors during pandemics. The themes presented in these movies represent realistic and relevant medical stories and experiences, making them effective educational tools as well as effective tools to influence social perceptions of and public attitudes towards the abilities, limitations, and experiences of medical doctors. These experiences have been visible and considerably important throughout the COVID-19 pandemic.

\section{Human/Animal Rights and Informed Consent}

This paper is a content analysis of realistic movies and did not involve human subjects or animals; thus, it did not require informed consent.

\section{Funding}

The study was not funded at any stage.

\section{Disclosure}

The author declares no conflicts of interest for this work.

\section{References}

1. Flores G. Doctors in the movies. Arch Dis Child. 2004;89 (12):1084-1088. doi:10.1136/adc.2003.048843

2. Dehority W. Infectious disease outbreaks, pandemics, and hollywood: hope and fear across nine decades of cinema. JAMA. 2020;323 (19):1878. doi:10.1001/jama.2020.7187

3. Melani L. “The Formalism-Realistic Scale." Handout. Literature and Film: Core Curriculum 3104. (Professor Lilia Melani.). Brooklyn: City University of New York; 2011. Available from: http://academic. brooklyn.cuny.edu/english/melani/film-and-lit/formalism-realism-hnd. pdf. Accessed October 12, 2020.

4. Crellin J, Briones AF. Movies in medical education. Acad Med. 1995;70:745. doi:10.1097/00001888-199509000-00001

5. Blasco PG, Moreto G. Teaching empathy through movies: reaching learners' affective domain in medical education. J Educ Learn. 2012;1 (1):22. doi:10.5539/jel.v1n1p22

6. Klemenc-Ketis Z, Kersnik J. Using movies to teach professionalism to medical students. BMC Med Educ. 2011;11(1):1-5. doi:10.1186/14726920-11-60

7. Lumlertgul N, Kijpaisalratana N, Pityaratstian $N$, et al. Cinemeducation: a pilot student project using movies to help students learn medical professionalism. Med Teach. 2009;31(7):e327-e332. doi:10.1080/01421590802637941 
8. Essex-Lopresti M. Centenary of the medical film. Lancet. 1997;349 (9055):819-820. doi:10.1016/S0140-6736(05)61747-3

9. Blasco P, Blasco M, Levites M, et al. Educating through movies: how hollywood fosters reflection. Creat Educ. 2011;2(3):174-180. doi:10.4236/ce.2011.23024

10. Tsianos E, Pappas G, Akritidis N, et al. Infectious disease in cinema: virus hunters and killer microbes. Clin Infect Dis. 2003;37 (1):939-942. doi:10.1086/377740

11. Braun V, Clarke V. Thematic analysis. In: Cooper H, Camic PM, Long DL, Panter AT, Rindskopf D, Sher KJ, editors. APA Handbook of Research Methods in Psychology, Vol. 2: Research Designs: Quantitative, Qualitative, Neuropsychological, and Biological. Washington, DC: American Psychological Association; 2012:57-71.

12. Guba EG, Lincoln YS. Competing paradigms in qualitative research. In: Denzin NK, Lincoln YS, editors. Handbook of Qualitative Research. Sage Publications, Inc; 1994:105-117.

13. Phillips H, David K. The Spanish Influenza Pandemic of 1918-1919: New Perspectives. Routledge; 2003.

14. Voyer B. Changes in the relations and roles of doctors and nurses. $\mathrm{Br}$ $J$ Health Care Manag. 2013;19(1):16-21. doi:10.12968/bjhc.20 13.19.1.16
15. Clark J, Armit K. Leadership competency for doctors: a framework. Leadersh Health Serv. 2010;23(2):115-129. doi:10.1108/1751187 1011040706

16. Li DKT. Challenges and responsibilities of family doctors in the new global coronavirus outbreak. FMCH. 2020;8:1. doi:10.1136/fmch2020-000333

17. Adepoju P. Lessons from ebola as DRC grapples with conflict, measles, and COVID-19. BMJ. 2020;370. doi:10.1136/bmj.m2879

18. Brody H, Avery EN. Medicine's duty to treat pandemic illness: solidarity and vulnerability. Hastings Cent Rep. 2009;39(1):40-48. doi: $10.1353 /$ hcr. 0.0104

19. Lippi D, Bianucci R, Donell S. Role of doctors in epidemics: historical perspectives and implications for COVID-19. Intern Emerg Med. 2020;15:1-2. doi:10.1007/s11739-020-02351-x

20. Chen F, Feudtner C, Rhodes L, et al. Role conflicts of physicians and their family members: rules but no rulebook. West $J$ Med. 2001;175 (4):236-239. doi:10.1136/ewjm.175.4.236
Advances in Medical Education and Practice

\section{Publish your work in this journal}

Advances in Medical Education and Practice is an international, peerreviewed, open access journal that aims to present and publish research on Medical Education covering medical, dental, nursing and allied health care professional education. The journal covers undergraduate education, postgraduate training and continuing medical education including emerging trends and innovative models linking education, research, and health care services. The manuscript management system is completely online and includes a very quick and fair peer-review system. Visit http://www.dovepress.com/testimonials.php to read real quotes from published authors. 